\title{
School Staffs' Experiences of Work and Working Conditions in Finnish and Estonian Schools
}

\author{
Terhi Saaranen*,1, Tiia Pertel ${ }^{2}$, Triinu Kalle ${ }^{2}$, Siivi Hansen ${ }^{2}$, Liana Varava ${ }^{2}$, Kädi Lepp ${ }^{3}$, Hannele \\ Turunen $^{1}$ and Kerttu Tossavainen ${ }^{1}$
}

\author{
${ }^{1}$ Department of Nursing Science University, University of Eastern Finland, Faculty of Health Sciences, Kuopio Campus, \\ Kuopio, Finland \\ ${ }^{2}$ Health Promotion Department University, The National Institute for Health Development, Tallinn, Estonia \\ ${ }^{3}$ Health Management, University, Tallinn University Haapsalu Collage, Foundation for School Health Care in Tallinn \\ Development, Tallinn, Estonia
}

\begin{abstract}
This paper describes the basic results of a survey into the occupational well-being of school staff related to various aspects of the 'worker and work' and working conditions, and to outline development requirements of school communities across Finland and Estonia. The baseline survey data were collected between 2009 and 2010 using the webbased Well-being at your work index questionnaire and analysed statistically. Using participatory action research, the project runs from 2009 until 2013 within the SHE (Schools for Health in Europe) network in Finland and Estonia. According to the results, approximately $40 \%$ of Finnish and $20 \%$ of Estonian participants were unhappy with the mental workload of their work. $67 \%$ of Finnish and $50 \%$ of Estonian participants felt unable to complete work at their workplace within working hours. In addition results showed the need for enhancement of working conditions in Finnish schools, e.g. providing air conditioning, and that Estonian school staff view their occupational well-being more positively than the Finns. The results apply to Finnish and Estonian school communities but could also be applied on a broader scale when developing international intervention research and development projects. This paper contains research-based information on the occupational well-being of school staff for use by school management and staff, and healthcare professionals.
\end{abstract}

Keywords: Action research, school, well-being, school staff, working conditions, school community.

\section{INTRODUCTION}

The health and well-being of teachers and other school staff members can be harmed by excessive workloads caused by, for example, inordinate demands made on a person's time and work resources [1-4]. However, it can also be seen that attributes such as an interesting job, good occupational health and good working conditions all contribute towards an environment where individuals can confront and manage stressful situations within schools.

Earlier studies have shown that teachers' work is considered mentally demanding [2, 3, 5-9]. For instance, according to Bauer et al. [6], nearly $30 \%$ of German teachers suffer from significant mental health problems. Similar results have also been found by Morena-April et al. [8]: more than one third of teachers in Spain reported having a high workload. Stress is caused by factors such as a hectic pace of work, lack of time, unfinished tasks and work requiring intense concentration [10] as well as a lack of recognition and appreciation and negative experiences with

*Address correspondence to this author at the Department of Nursing Science University, University of Eastern Finland, Faculty of Health Sciences, Kuopio Campus, Kuopio, Finland; Tel: +358 500 940242;

Fax:+358 17162 632; E-mail: terhi.saaranen@uef.fi pupils and their parents senior colleagues and supervisors [2, $6,11]$.

In addition to the negative effect on mental faculties, work-related stress and an excessive workload can also cause teachers physical [9] and psychosomatic symptoms (such as headaches, insomnia) [2]. A high workload for teachers carries a high risk of experiencing maladies such as the emergence of pains in the neck and upper limb area [12] as well as voice-related problems [13].

In addition to excessive workloads, working conditions have also been linked to work-related stress and the wellbeing of school staff $[4,5,14]$. Several international and national studies have indicated that there needs to be an improvement in the maintenance of school buildings, the ventilation of teaching premises, acoustics, teaching aids and furniture $[10,15,16]$. For example, according to earlier studies, the problems of poor indoor air quality and water damage in schools are common and can increase illnesses such as allergies and asthma in pupils and members of staff [16-19]. In 2003, Whelan et al. [20] showed that schoolteachers report a higher prevalence of work-related upper respiratory symptoms, chest illness and cold and flu than the general working population of the USA. Studies that deal with the working conditions in schools, covering issues 
such as mould and moisture, have often been conducted in the United States and in the Nordic countries [18-19]. However, no previous research can be found on the working conditions within Estonia's schools, addressing issues such as the quality of indoor air.

Moreover, there have been several research studies into the connection between the perception among teaching professionals of their health and well-being in relation to their age $[6,9]$, gender $[4,6,8,9]$, the nature of their contract (part-time or full-time) and different types of employment (permanent or fixed-term) [4, 6, 21]. However, there is a paucity of research on the occupational well-being of school staff from the point of view of different occupational groups (for instance, members of the supporting service staff other than teachers) (see, for example [22]).

As a person grows older, their health problems usually increase (e.g., [9]). Women tended to consider their health and well-being to be poorer than men (e.g., $[8,9]$, and the occupational well-being of teachers appears to be better for part-time workers than for permanent or full-time teachers [4]. According to Konu et al. [4], part-time workers rated their chances of self-fulfilment more highly than permanent and full-time workers. However, there are contradictory results: Bauer et al. [6] did not detect a link between age, gender, or full/part-time teaching (see also [21]) and mental health problems. In fact, it is the personal characteristics of teachers such as their attitude towards harmful issues and new situations and their poor self-direction skills that can be considered the main factors affecting occupational wellbeing [8].

The school community plays an extremely important role in promoting occupational well-being within schools, but each member of staff is the one most responsible for their own physical, psychological and social well-being [23]. Therefore, it is very important that each member of staff takes care of issues such as their own physical fitness [9, 24], something that has been found to have beneficial effects on a person's mental and social well-being.

This study was based on the premise that the occupational well-being of school staff can be promoted through actions that maintain their ability to work. These actions are: promoting individuals' health and resources; improving the functionality of the working community and organisation; developing professional competence and improving work and working conditions [25]. The baseline results of the action research project that targeted the areas of 'the worker and work' (health, mental and physical workload, individual resources and the factors influencing them such as mentoring and rehabilitation) and working conditions (physical working environment including physical, biological and chemical factors and safety at work including working postures and equipment) are presented here, along with an outline of development needs of the Finnish and Estonian school communities. The goal of these baseline results was to produce descriptive research information that could be used in the development of occupational well-being in schools within this action research project (Fig. 1).
Implementation of this project occurred between the autumn of 2009 and the winter of 2010. During this period, 21 Finnish schools and 40 Estonian schools committed to a project entitled "Promotion of school community staff's occupational well-being - action research project in Finland and Estonia, 2009 - 2013”. The project is part of a larger SHE (Schools for Health in Europe) programme implemented in Finland and Estonia. Therefore, the schools in the project were chosen from the SHE network's schools in Finland and Estonia on the basis of voluntariness. A requirement for the participants was that the schools should be comprehensive schools (including pre-schools; children aged 6, and grades 1-9; children aged 7-16) or upper secondary schools (grades 1-3; youths mostly aged 17-19). Research on occupational well-being has been previously conducted in some Finnish schools [1, 4, 22, 24], but it is a fairly new concept in Estonian schools. Additionally, cooperation in the project was easy to conduct geographically as Finland and Estonia are neighboring countries. Moreover, co-operation between Finnish and Estonian colleagues was important and flexible through the SHE network. The research framework also allowed comparison between the results gathered from the Finnish schools with the data from the Estonian schools.

\section{Aim of the Study and the Study Questions}

The aim of this paper is to describe the baseline results of the action research project intended to improve the occupational well-being of school staff. The most problematic factors in the areas of the 'worker and work', and working conditions are presented, along with an outline of development requirements within the school communities.

The specific questions were:

1) What were the most problematic factors in the aspects of 'worker and work', in terms of both the respondents' opinions and the need for development in Finland and Estonia at the start of the project?

2) What were the most problematic factors in the aspects of working conditions in terms of both respondents' opinions and the need for development in Finland and Estonia?

3) What is the connection between the occupational groups (teacher, principal, school nurse, support staff of the school, other occupational groups) and the sum variables of the aspects in the areas 'worker and work' and working conditions?

\section{MATERIALS AND METHODOLOGY}

\section{Questionnaire and Data}

The data have been collected using the quantitative webbased Well-being at your work index questionnaire from the entire staff (principals, teachers, school nurses, other support staff and other occupational group, such as cleaners and cooks) at schools in Finland $(\mathrm{N}=844)$ and in Estonia $(\mathrm{N}=$ 1978), between the autumn of 2009 and the winter of 2010.The response rate was $58 \%$ in the Finnish $(n=486)$ and $67 \%$ in the Estonian $(n=1330)$ schools. 


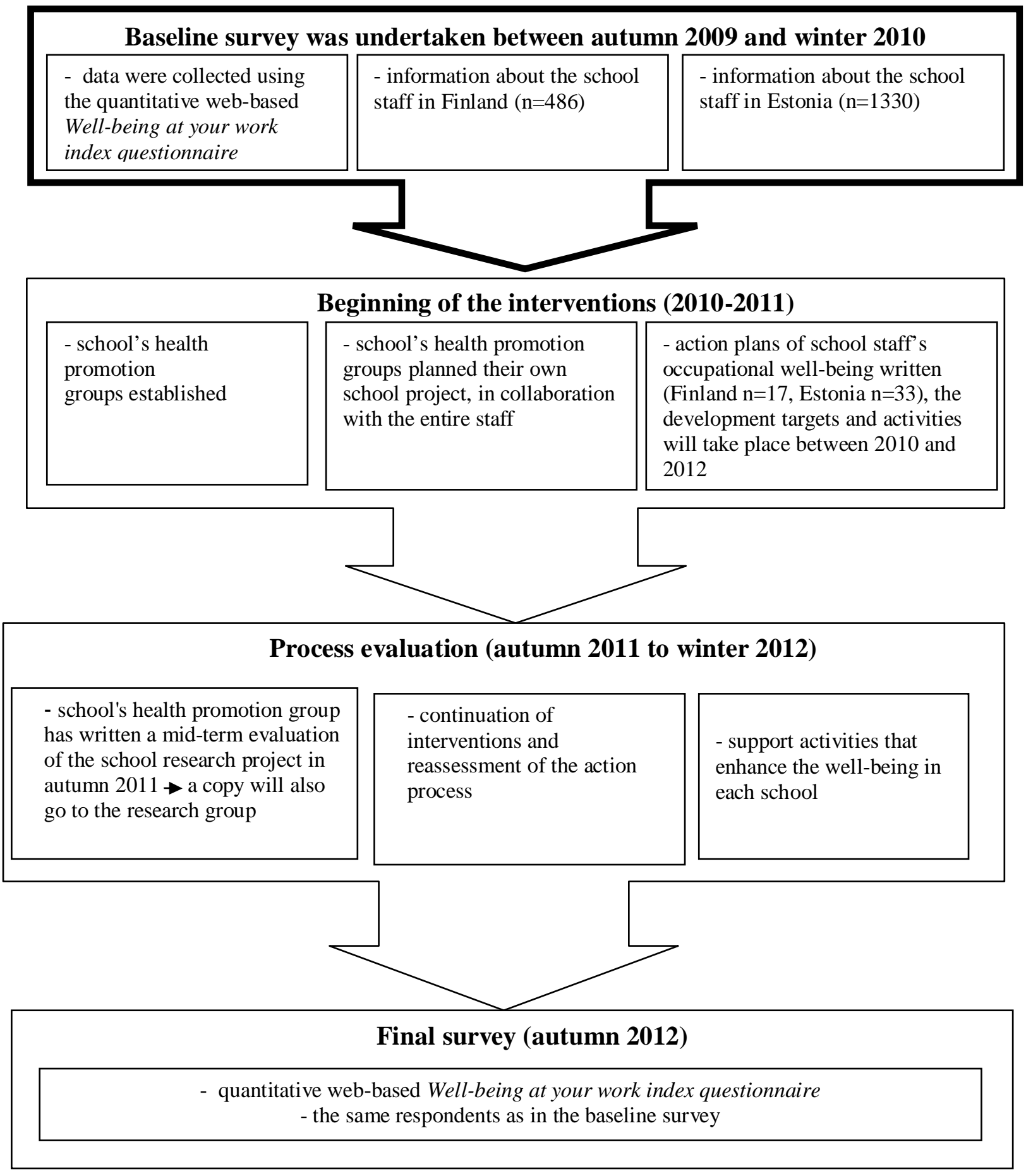

Fig. (1). Implementation of the action research project entitled "Promotion of school community staff's occupational well-being - action research project in Finland and Estonia, 2009-2013".

The Well-being at your work index questionnaire was developed and tested in earlier studies [1,25]. Apart from the original Finnish version, it has been translated and tested in English and Estonian. In this study, the Finnish version of the questionnaire was used by the Finnish respondents and the Estonian version by the Estonians.

The questionnaire contained questions about background information (ten questions with open and classified variables). The questionnaire then aimed to present occupational well-being and satisfaction in terms of actions that maintain the ability to work as well as the different aspects of occupational well-being (working conditions, the worker and work, working community and professional competence) and their need for development in school communities. Earlier literature and research also support the view that occupational well-being is affected by these four aspects [e.g., 22, 25]. Occupational well-being and 
satisfaction with the actions maintaining the ability to work were explored with four Likert scale (1-5) variables. Of the different aspects, working conditions (12 variables), worker and work (12 variables), working community (20 variables) and professional competence (seven variables) (altogether 51 variables of four aspects), the staff's opinion and need for development were investigated separately using the Likert scale (1-5).

This article describes background information (workplace, profession, gender, age, contract type), teachers' opinions on aspects of their working conditions, 'worker and work', and developmental needs. Working community and professional competence have been described in a separate international publication [23].

\section{Data Analysis}

Background information gathered from the school staff was examined using descriptive statistics (frequencies and percentages; see Table 1). The different aspects of occupational well-being such as working conditions and the 'worker and work' were evaluated on the basis of five point Likert scale variables. Staff members were asked to give

Table 1. Background Information on the School Staff in Finland $(n=486)$ and Estonia $(n=1330)$

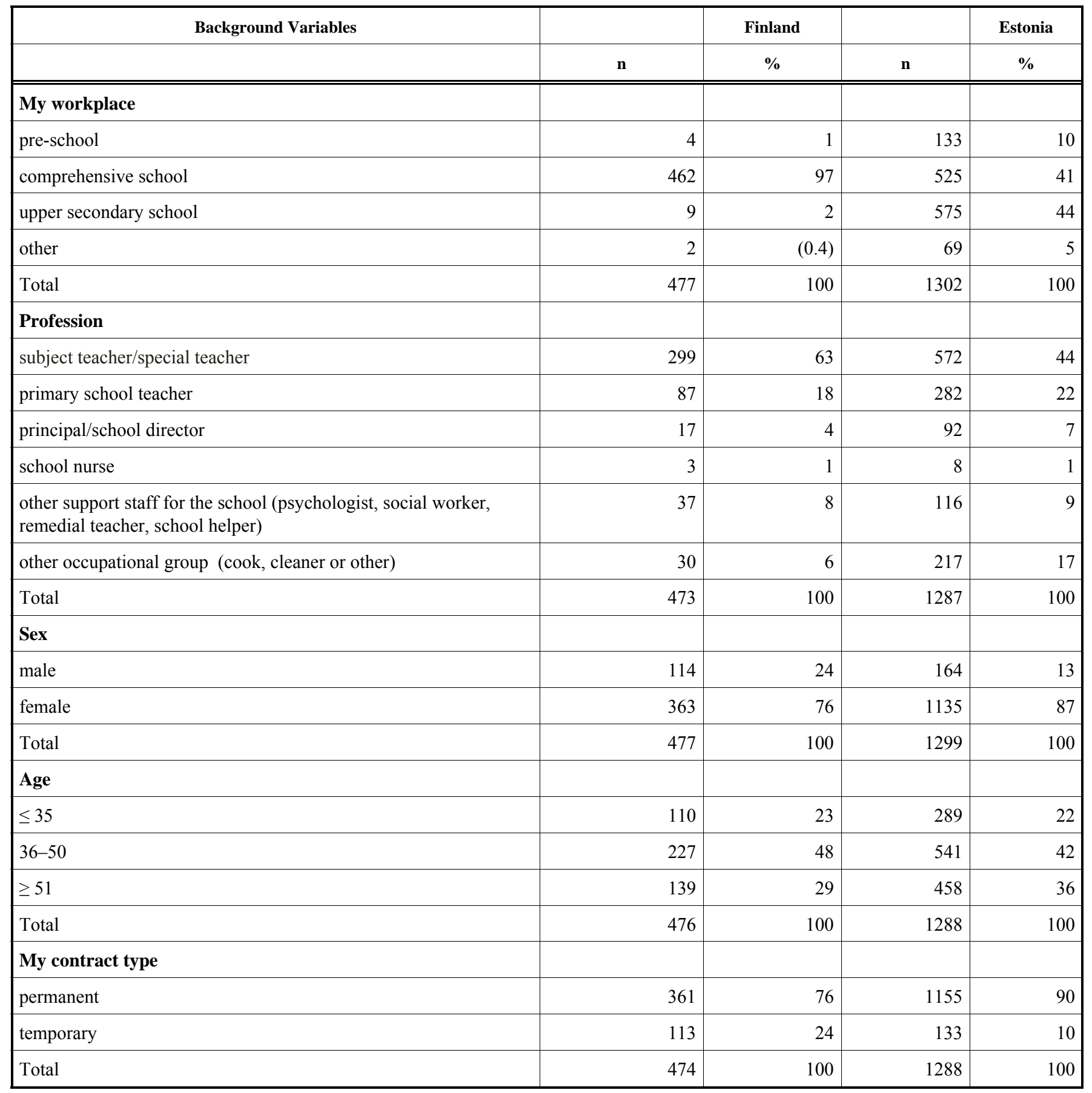


their opinions of each statement (12 statements related to working conditions and 12 statements related to the 'worker and work') separately (from $1=$ totally disagree to $5=$ totally agree) and to evaluate the need for development of the issues presented in the statements (from $1=$ needed very much to $5=$ not needed at all). To summarise the data, sum variables were formulated based on the results of a factor analysis conducted based on data from an earlier study on the occupational well-being aspects (working conditions, worker and work, working community and professional competence) and the Well-being at your work index questionnaire [25], in which the variables of working conditions (12 variables), as well as the worker and work variables (12 variables), were formed into four factors. The factors were analogous in the opinion and need for development sections.

Therefore, in the 'worker and work' aspect, four sum variables were formed out of the 12 variables for the two sections 'opinion' and 'need for development' in this article: workload, activities supporting personal resources at work, functioning of occupational healthcare, and urgency and pace of work (Table 2). Similarly, in the 'working conditions' aspect, four sum variables were formed from the 12 variables in this section based on both the opinion and the need for development sets of answers. These variables included working space, postures and equipment, physical factors, no chemical and biological factors and permanent working site (Table 5).

Separately describing the results on the aspects of 'working conditions' and 'worker and work' for both the section on opinion and the section on need for development in Finland and Estonia (Table 2, 5) also allow for a comparison of the samples (mean, standard deviation, MannWhitney $U$ test) between Finland and Estonia. In addition, in this article, the staff members' responses for individual variables are presented as percentages for both countries in Tables $\mathbf{2}$ and $\mathbf{5}$ for which the five-class Likert scale has been converted to a three-class scale.

The connection between the background variables and the sum variables was tested in this study using a one-way variance analysis (Table 3). Only the connection between the 'profession' background variable and the sum variables is discussed here in more detail (Table 4). The threshold for statistical significance ( $p$-value) was 0.05 for the Finnish data and 0.001 for the Estonian data. The difference in value was due to the different sizes of the datasets from Finland ( $\mathrm{n}$ $=486)$ and Estonia $(n=1330)$ (see Table 3 and 4) [26].

\section{Ethical Considerations}

This baseline survey, as a part of the SHE action research study, has been carried out according to a supporting statement that was obtained from the Research Ethics Committee of the Hospital District of Northern Savo in September 2009. Research permission was obtained from the participating organisations in Finland (University of Eastern Finland, The Finnish Centre for Health Promotion) and Estonia (the National Institute for Health Development) as well as from each leader of the participating schools. The data used in this baseline survey were collected from Finland and Estonia using an electronic form and each respondent was informed about the voluntary nature and integrity of the survey before responding. The well-being at your work index questionnaire and the creation of sum variables from the individual variables (e.g., 'worker and work' and working conditions) are described in greater depth in a separate article [25].

\section{RESULTS}

\section{Background}

The participants in this baseline survey primarily worked in comprehensive schools (including pre-school) or upper secondary schools in both Finland (100\%, exactly $99.6 \%)$ and Estonia (95\%). Some of the participants reported their actual workplace as somewhere else (e.g., cleaning staff from an outside organisation), but these employees also worked within a school community. All the staff of the schools participated in the survey; the largest professional group comprised subject teachers/special teachers and primary school teachers in both Finland (81\%) and Estonia $(66 \%)$. More background information on the school staff in Finland and Estonia is presented in Table 1. Statistical significance, 'worker and work', and work conditions are also described in the results section using sum variables based on occupational groups.

\section{The Aspect of the 'Worker and Work'}

'Worker and work' has been condensed into four sum variablesbased on both the opinion and the need for development sections: workload, urgency and pace of work, activities supporting personal resources at work, and functioning of occupational healthcare (Table 2). The workload of school staff can be considered to be at a satisfactory level based on both the opinion of the respondents (mean: Finland $=3.30$ and Estonia 3.75) and their views on developmental needs (mean: Finland $=3.42$ and Estonia 3.67). Examination of individual variables from 'worker and work' also revealed problem areas and developmental needs. More than two fifths of the Finnish respondents (43\%) and one fifth of the Estonian respondents $(20 \%)$ were not satisfied with the suitability of the mental workload of their occupation. Moreover, two thirds of the Finnish respondents and roughly one third of the Estonian respondents indicated a particular problem relating to the uneven distribution of work i.e. there are extremely busy periods of work that cause particular strain. The Estonian data revealed a statistically significant connection between profession and workload (Table 3). School health nurses were most satisfied according to the sum variable workload, while subject teachers/special education teachers were the least satisfied group (Table 4).

The Finnish respondents had the lowest mean value of the sum variable 'urgency and pace of work' (Opinion section: mean in Finland $=2.62$ and mean in Estonian $=$ 3.16). An inspection of individual variables reveals that 67 $\%$ of the Finnish respondents and $50 \%$ of the Estonian respondents reported that they were unable to finish their work at their workplace within their working hours. Furthermore, $48 \%$ of the Finnish and $34 \%$ of the Estonian respondents were not satisfied with the number of breaks and rests they were able to take (Table 2). In Finland, the staff members most satisfied with the sum variable 'urgency and pace of work' were school nurses, other support staff and 
Table 2. Means and Standard Deviations (SDs) of the Sum Variables of 'Worker and Work' in Terms of Replies for both the Opinion and the Need for Development in Finland $(n=486)$ and Estonia $(n=1330)$. The Table also Shows the Answers of the Staff Members to Each Individual Variable as a Percentage

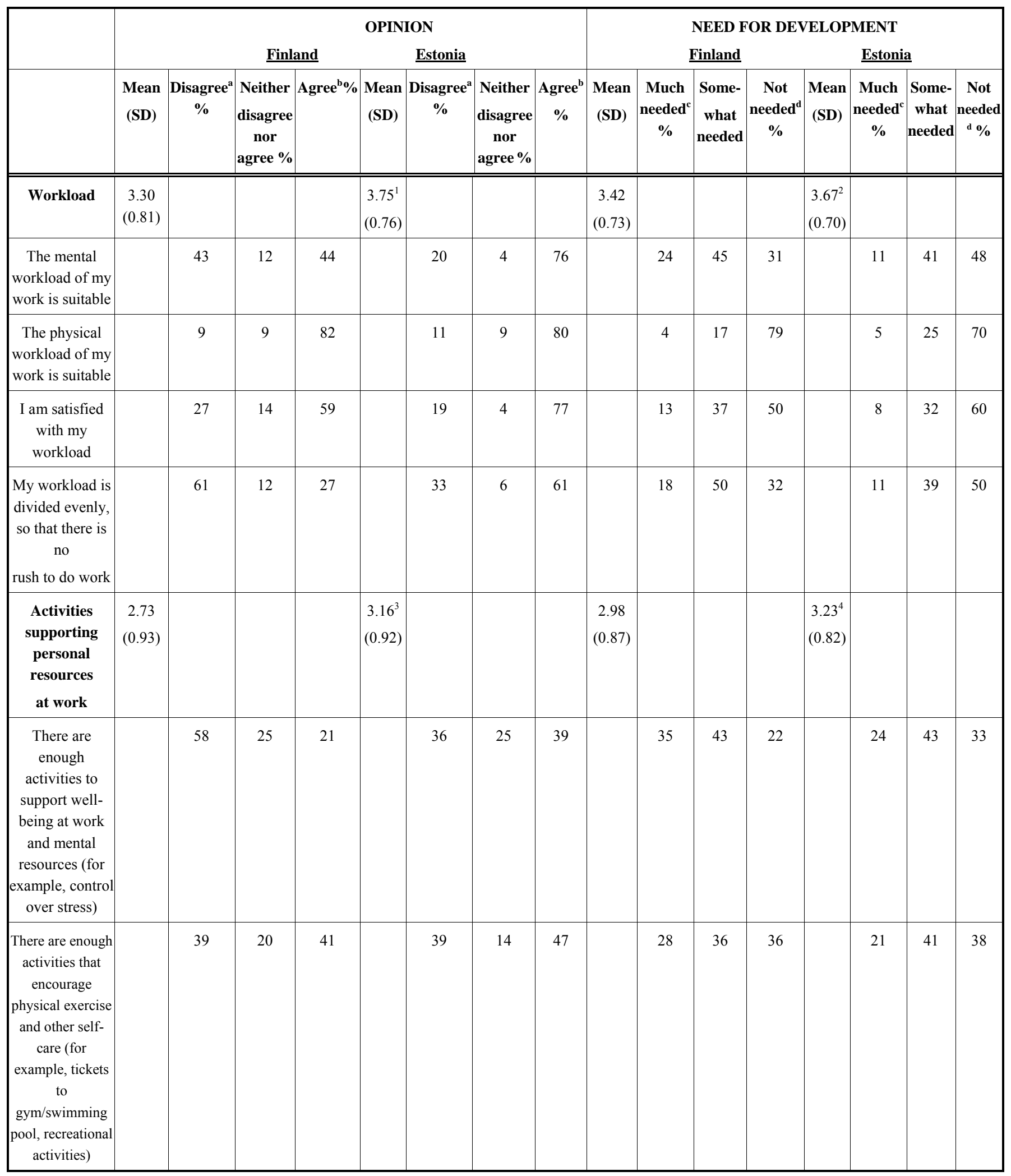


Table 2. Contd.....

\begin{tabular}{|c|c|c|c|c|c|c|c|c|c|c|c|c|c|c|c|c|}
\hline & \multicolumn{8}{|c|}{ OPINION } & \multicolumn{8}{|c|}{ NEED FOR DEVELOPMENT } \\
\hline & $\begin{array}{c}\text { Mean } \\
\text { (SD) }\end{array}$ & $\begin{array}{c}\text { Disagree }^{\mathrm{a}} \\
\%\end{array}$ & $\begin{array}{c}\text { Neither } \\
\text { disagree } \\
\text { nor } \\
\text { agree \% }\end{array}$ & Agree $^{\mathbf{b}} \%$ & $\begin{array}{c}\text { Mean } \\
\text { (SD) }\end{array}$ & $\begin{array}{c}\text { Disagrea }^{\mathrm{a}} \\
\%\end{array}$ & $\begin{array}{c}\text { Neither } \\
\text { disagree } \\
\text { nor } \\
\text { agree \% }\end{array}$ & $\begin{array}{c}\text { Agree }^{\mathrm{b}} \\
\%\end{array}$ & $\begin{array}{l}\text { Mean } \\
\text { (SD) }\end{array}$ & $\begin{array}{c}\text { Much } \\
\text { needed }^{\mathrm{c}} \\
\%\end{array}$ & $\begin{array}{c}\text { Some- } \\
\text { what } \\
\text { needed }\end{array}$ & $\begin{array}{c}\text { Not } \\
\text { needed }^{\mathrm{d}} \\
\%\end{array}$ & $\begin{array}{l}\text { Mean } \\
\text { (SD) }\end{array}$ & $\begin{array}{c}\text { Much } \\
\text { needed }^{\mathrm{c}} \\
\%\end{array}$ & $\begin{array}{c}\text { Some- } \\
\text { what } \\
\text { needed }\end{array}$ & $\begin{array}{c}\text { Not } \\
\text { neede } \\
d^{\text {d } \%}\end{array}$ \\
\hline $\begin{array}{c}\text { Functioning of } \\
\text { occupational } \\
\text { health care }\end{array}$ & $\begin{array}{c}2.89 \\
(0.93)\end{array}$ & & & & $\begin{array}{l}3.07^{5} \\
(0.95)\end{array} \mid$ & & & & $\begin{array}{c}3.15 \\
(0.97)\end{array}$ & & & & $\begin{array}{l}3.19^{6} \\
(0.95)\end{array}$ & & & \\
\hline $\begin{array}{l}\text { Health check-ups } \\
\text { are regular }\end{array}$ & & 49 & 20 & 31 & & 26 & 11 & 63 & & 31 & 36 & 33 & & 19 & 35 & 36 \\
\hline $\begin{array}{l}\text { Health check-ups } \\
\text { are my health }\end{array}$ & & 31 & 34 & 35 & & 24 & 32 & 34 & & 28 & 35 & 37 & & 18 & 41 & 41 \\
\hline $\mid \begin{array}{c}\text { I am able to have } \\
\text { breaks and } \\
\text { periods of rest in } \\
\text { my work }\end{array}$ & & 48 & 13 & 39 & & 34 & 8 & 58 & & 24 & 40 & 36 & & 10 & 33 & 57 \\
\hline
\end{tabular}


Table 3. The Connection Between the Background Variables and the Sum Variables Relating to 'Worker and Work' and 'Working Conditions' (p-value tested with one-way analysis of variance)

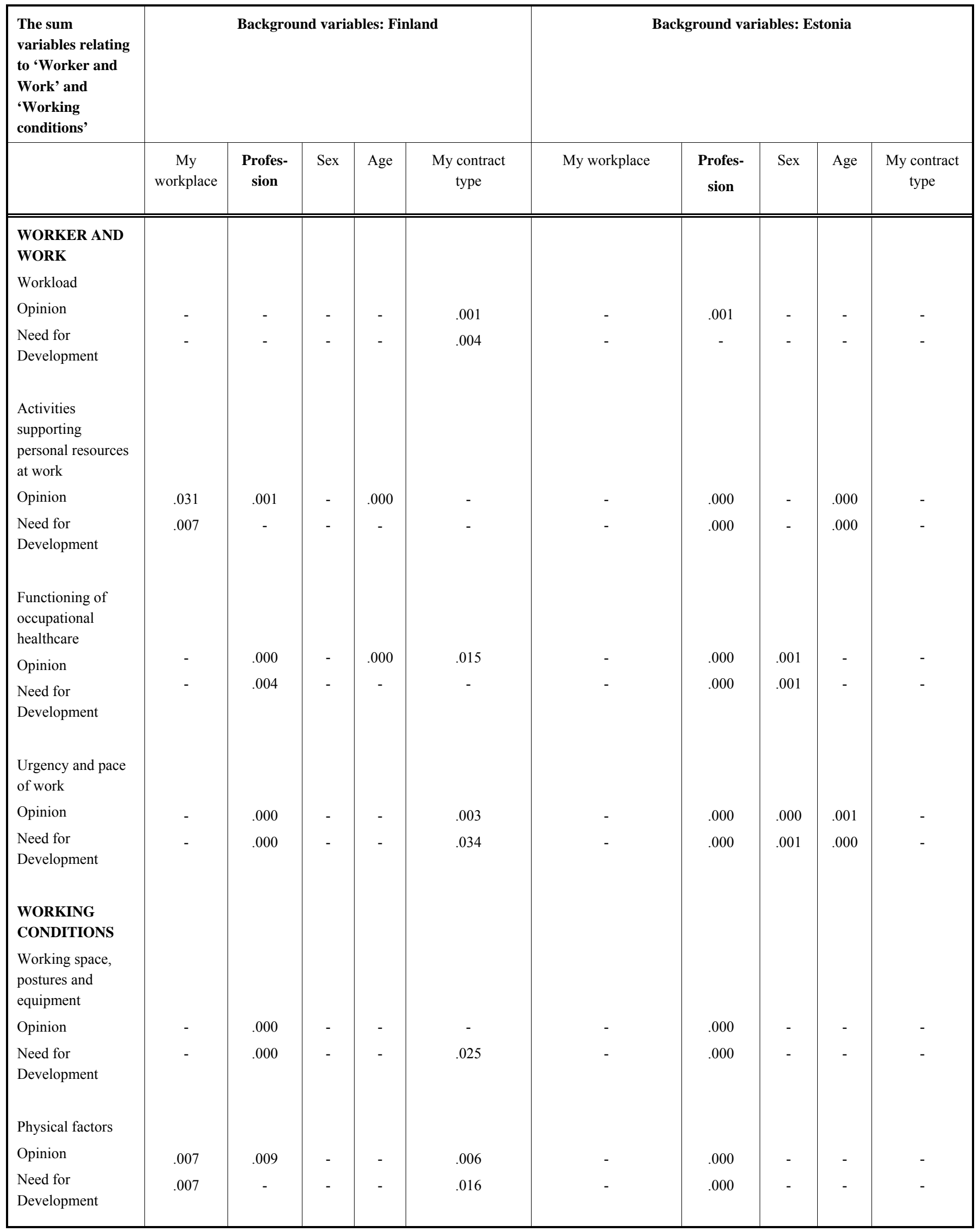


Table 3. Contd.....

\begin{tabular}{|c|c|c|c|c|c|c|c|c|c|c|}
\hline \multirow{2}{*}{$\begin{array}{l}\text { The sum } \\
\text { variables relating } \\
\text { to 'Worker and } \\
\text { Work' and } \\
\text { 'Working } \\
\text { conditions' }\end{array}$} & \multicolumn{5}{|c|}{ Background variables: Finland } & \multicolumn{5}{|c|}{ Background variables: Estonia } \\
\hline & $\begin{array}{c}\text { My } \\
\text { workplace }\end{array}$ & $\begin{array}{l}\text { Profes- } \\
\text { sion }\end{array}$ & Sex & Age & $\begin{array}{l}\text { My contract } \\
\text { type }\end{array}$ & My workplace & $\begin{array}{c}\text { Profes- } \\
\text { sion }\end{array}$ & Sex & Age & $\begin{array}{l}\text { My contract } \\
\text { type }\end{array}$ \\
\hline \multicolumn{11}{|l|}{$\begin{array}{l}\text { No chemical and } \\
\text { biological factors }\end{array}$} \\
\hline Opinion & - & .000 & .023 & - & - & - & .000 & - & - & - \\
\hline $\begin{array}{l}\text { Permanent } \\
\text { working site }\end{array}$ & & & & & & & & & & \\
\hline Opinion & - & - & - & - & - & - & - & .000 & - & - \\
\hline $\begin{array}{l}\text { Need for } \\
\text { Development }\end{array}$ & - & - & - & - & - & - & - & - & - & - \\
\hline
\end{tabular}

Note. Threshold for statistical significance: Finnish data $\mathrm{p} \leq 0.05$ and Estonian data $\mathrm{p} \leq 0.001$. The different limit values are based on the different dataset sizes.

Table 4. The Connection Between the Background Variable 'Profession' and the Sum Variables of 'Worker and Work' and 'Working Conditions' (p-value tested with one-way analysis of variance)

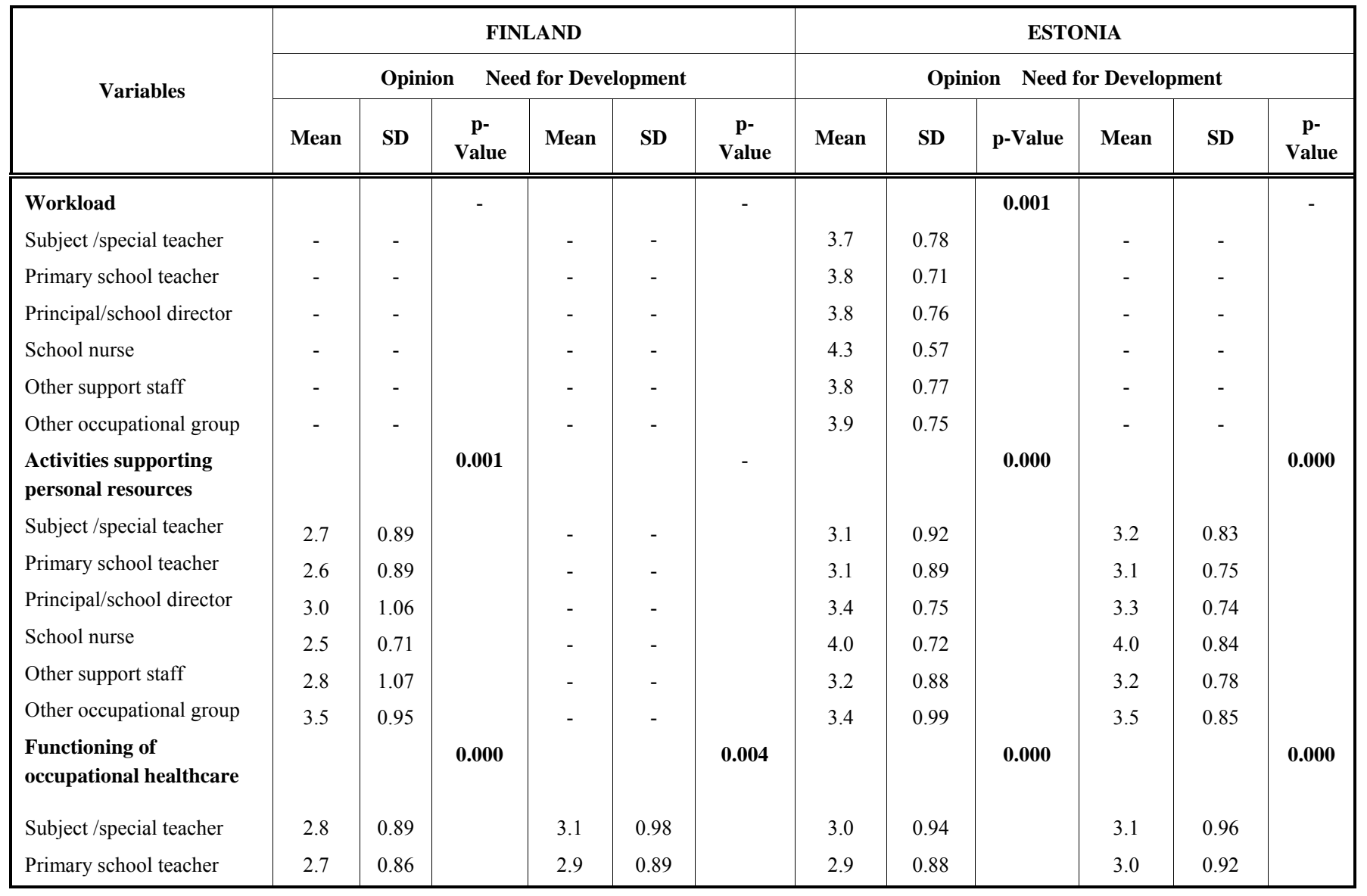


Table 4. Contd.....

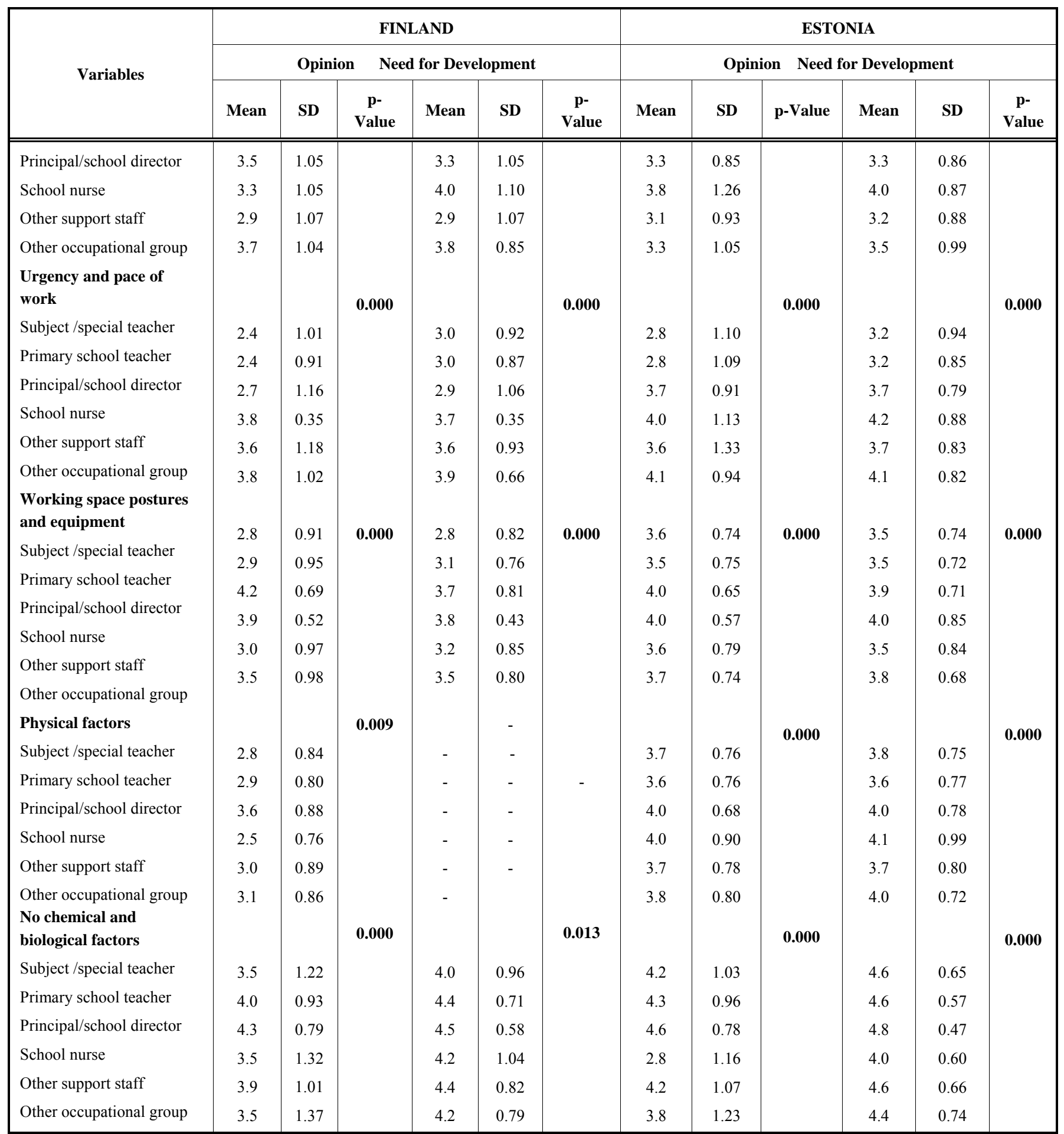

Note. Threshold for statistical significance: Finnish data $\mathrm{p} \leq 0.05$ and Estonian data $\mathrm{p} \leq 0.001$. The different limit values are based on the different dataset sizes.

school director) were less contented. In the Estonian data, the most positive results came from school nurses and other occupational groups as opposed to other professions (Table 4).

In the section on opinions, the mean value for the sum variable 'activities supporting personal resources at work' was 2.73 for the Finnish and 3.16 for the Estonian respondents. In the section on the needs for development, these means were 2.98 for the Finnish and 3.23 for the Estonian respondents. There appears to be a need for development particularly in the areas of mental resources and activities which support well-being at work. However, more than a quarter of the Finnish $(28 \%)$ and one fifth of the Estonian $(21 \%)$ respondents felt that there is a lot to improve in the area of activities that encourage physical exercise and other self-care (Table 2). In Finland, those most 
satisfied with activities supporting personal resources were other occupational groups and principals/school directors. Similarly, in Estonia, the groups most satisfied with activities which support personal resources were school nurses, principal/school directors and other occupational groups (Table 4).

Based on the sum variable 'functioning of occupational healthcare', there is a need in Finland to develop health check-ups for school staff; $49 \%$ of the respondents were dissatisfied with the regularity of health check-ups and $31 \%$ felt that this area needs much more development (Table 2). The Estonian respondents felt that there is a considerable need for the development of opportunities to receive rehabilitation based on occupational healthcare assessment (37\% of the respondents replied that development is "much needed"). The respondents most content with the functioning of occupational healthcare in both Finland and Estonia came from the groups principals/school directors, other occupational groups, and school nurses (Table 4).

\section{The Aspect of Working Conditions}

'Working conditions' has been condensed into four sum variables on the opinion and the need for development sections: 'working space, postures and equipment', 'physical factors', 'no chemical and biological factors' and 'permanent working site'. In Finland, development is particularly needed in the areas of 'working space, postures and equipment' and 'physical factors' based on the respondents' opinions and their views on development needs (Table 5; see means of the sum variables for both the opinion and the need for development responses in Finland and Estonia). Based on individual variables, Finnish respondents were most dissatisfied with the air conditioning of their workplace (Opinion: 62\% disagree; Need for development: $47 \%$ much needed) and in Estonia with a very high noise level in the workplace (Opinion: 40\% disagree; Need for development: $17 \%$ much needed; see Table 5). The most positive results were seen for the sum variable 'working space, postures and equipment' from the groups of principals/school directors and other occupational groups and school nurses (Table 4). The most positive evaluations with respect to the sum variable 'physical factors' came from the group of principals/school directors in both Finland and Estonia.

The mean values of the sum variables 'no chemical and biological factors' and 'permanent working site' can be considered satisfactory or good (means 3.62-4.55) based on the results from both Finland and Estonia (Table 5; see means of the sum variables with respect to responses for both opinion and the need for development in Finland and Estonia). When examining the results, one must consider that there is a significant standard deviation (SD) in these sum variables. For example, the sum variable for chemical and biological factors does not affect all members of a school staff. Out of the occupational groups, the most positive results with respect to chemical and biological risk factors were gathered from principals and school directors as well as from primary school teachers. These results can be considered to indicate that members of these groups seldom or never deal with harmful substances in their work (for instance, vaccine agents handled by school health nurses and detergents handled by cleaning staff).

It is also worth noting that, when examining all sum variables and individual variables (Tables 2 and 5), it is possible to observe that throughout the study, the results from Estonia are statistically significantly more positive than those from Finland (see Mann-Whitney U test results: $p=$ $0.000)$.

\section{DISCUSSION}

Based on these results, it was interesting to note that the Estonians perceived the well-being of school staff more positively than the Finns in relation to 'work conditions' as well as 'worker and work'. The results are descriptive and do not therefore explain why the results from Estonia were more positive than those from Finland. The primary goal of the results was to provide descriptive information on the well-being of school staff, helping the schools to develop their current practices and giving them relevant information that can be used when planning for the future (see also [4]).

These baseline results provided information for the school staff and research group suggesting ways to plan and carry out the development project's interventions in the school communities. In practice, every school community in this project has been given their own summary of the baseline results for the spring-summer term of 2010, which they can utilise in their school community (Fig. 1). Additionally, school communities have been offered country-specific summaries of the results on the baseline situation, which they have been able to compare to their own school's results.

Subsequently, between the autumn 2010 and the spring 2011, the staff of each school and their school's health promotion group (3-6 persons selected from the school staff) planned their own school project and its interventions cooperatively based on the baseline survey's quantitative results in Finland and Estonia. Development areas were chosen, particularly aspects providing the worst results of the survey. The 17 Finnish and 33 Estonian school health promotion groups wrote their school's personal action plan, which itemizes, for example, the school staff's resources, required developments, the targets for development and interventions, scheduled for the years 2010-2012. In a typical case, every school specified up to three objectives as concretely as possible (e.g., related to the development of the working atmosphere, working conditions or the employee's mental or physical condition) to which the interventions were connected so that it would be possible to carry out the developments. $\mathrm{Wu}$ et al. [5] have also reported that interventions are effective in reducing the causes of teachers' stress, increasing their ability to cope and improving their ability to work.

The school action plans were also returned to the members of the research group, who made summaries of the school-specific interventions in both Finland and Estonia. The Finnish and Estonian schools' health promotion groups have also written a mid-term evaluation of the school research project and of the implementation of the 
Table 5. Means and Standard Deviations (SDs) of the Sum Variables of 'Working Conditions' in Terms of Replies for both the Opinion and the Need for Development in Finland $(n=486)$ and Estonia $(n=1330)$. The Table also Shows the Answers of the Staff Members to Each Individual Variable as a Percentage

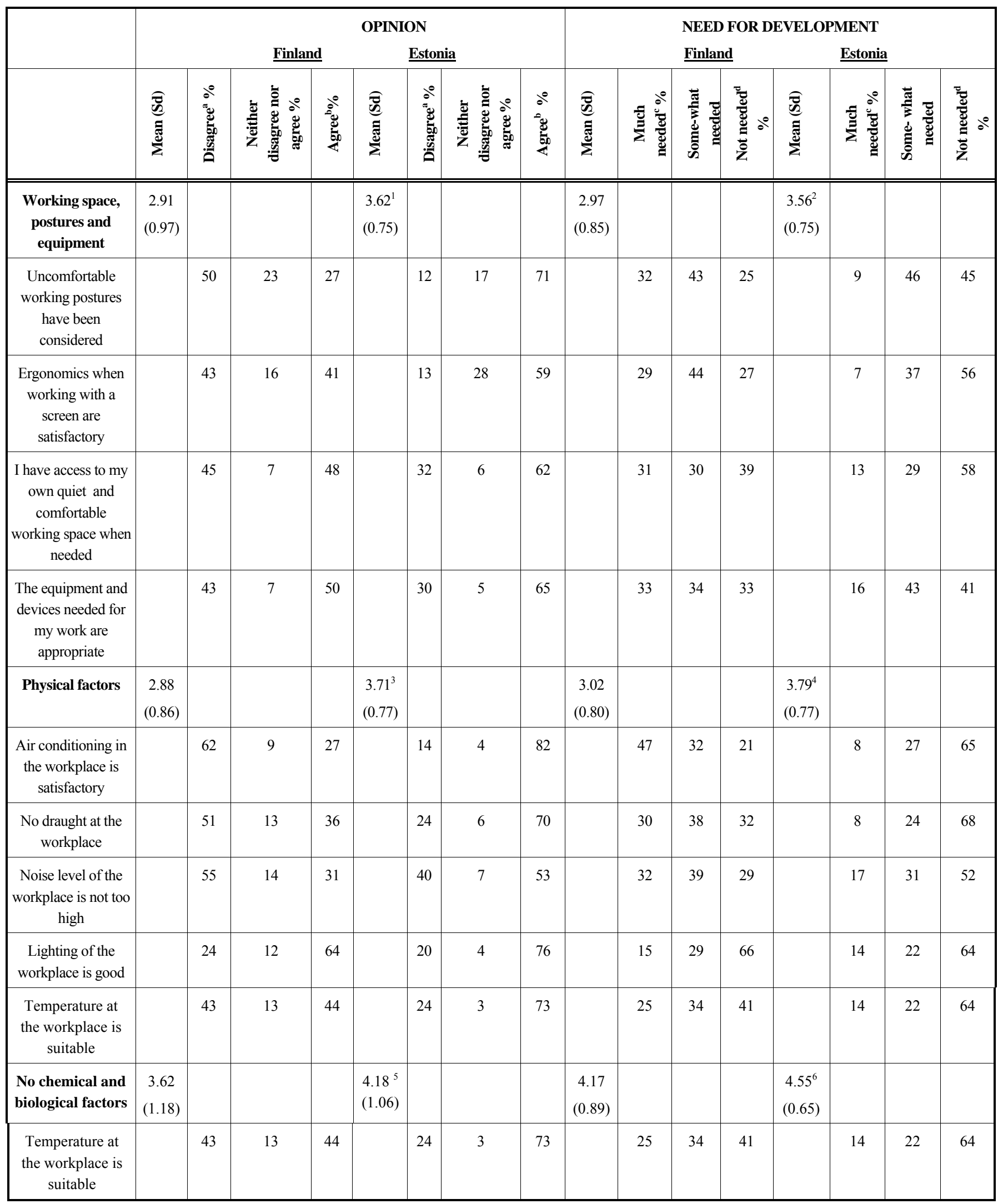


Table 5. Contd....

\begin{tabular}{|c|c|c|c|c|c|c|c|c|c|c|c|c|c|c|c|c|}
\hline & \multicolumn{8}{|c|}{ OPINION } & \multicolumn{8}{|c|}{ NEED FOR DEVELOPMENT } \\
\hline & 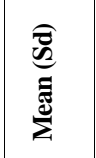 & 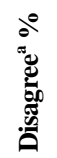 & 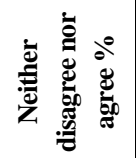 & 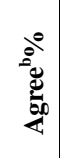 & 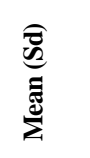 & 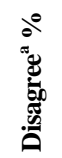 & 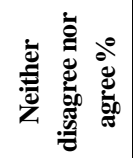 & 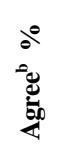 & 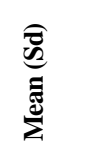 & 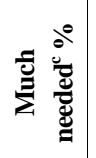 & 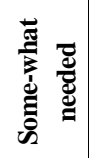 & 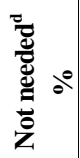 & $\begin{array}{l}\text { 氙 } \\
\text { हैँ }\end{array}$ & 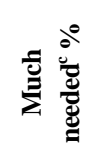 & 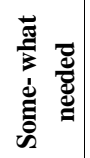 & 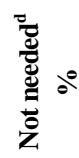 \\
\hline $\begin{array}{c}\text { Exposure to } \\
\text { harmful chemical } \\
\text { substances at } \\
\text { work is not } \\
\text { possible }\end{array}$ & & 27 & 12 & 61 & & 14 & 7 & 79 & & 7 & 14 & 79 & & 2 & 10 & 88 \\
\hline $\begin{array}{c}\text { Permanent } \\
\text { working site }\end{array}$ & $\begin{array}{c}3.79 \\
(1.55)\end{array}$ & & & & $\begin{array}{l}4.24^{7} \\
(1.17)\end{array}$ & & & & $\begin{array}{c}3.93 \\
(1.16)\end{array}$ & & & & $\begin{array}{l}4.46^{8} \\
(0.83)\end{array}$ & & & \\
\hline $\begin{array}{l}\text { My working site } \\
\text { is permanent, and } \\
\text { I don't need to } \\
\text { walk long } \\
\text { distances from } \\
\text { one site to } \\
\text { another (for } \\
\text { example a teacher } \\
\text { or a cleaner } \\
\text { moving to another } \\
\text { school during the } \\
\text { workday) }\end{array}$ & & 27 & 4 & 69 & & 14 & 2 & 84 & & 11 & 19 & 70 & & 3 & 9 & 88 \\
\hline
\end{tabular}

interventions in autumn 2011-winter 2012. Final surveys will be collected with a quantitative web-based Well-being at your work index questionnaire from the entire staff of the schools (the principals, teachers, school nurses, and other staff, such as cleaners and cooks) in the autumn of 2012 (Fig. 1). These research results of this study also allow the occupational well-being of school staff in Finland and Estonia at baseline with later points during the process and in the final phase of the project.

The results of this baseline study indicated that the mental strain faced by staff in Finnish and Estonian schools was a pivotal factor in occupational health. The work of school staff members includes very busy periods (e.g. the final stages of semesters and class periods) and there is insufficient time allotted for rest breaks. Furthermore, staff members felt that there was not enough time to finish work tasks. In order to prevent workers being overloaded with too many tasks and therefore prevent work-related exhaustion, interventions must improve occupational well-being (for example, how to better manage busy work schedules at work and within the working community with the help of development actions) and increase mental resources of staff in relation to the demands of their work (for example, with additional training). Furthermore, staff members felt that there is a need to develop those activities that encourage physical exercise and other self-care (such as recreational activities and gym access) thus providing resources for their physical, as well as mental, well-being.

However, the differences between the two countries (that is, the more positive results from Estonia) require an examination of the underlying reasons, including differences within both the research group and the schools involved in the research. Factors considered include the problems of 
indoor air quality and contamination by mould in several Finnish schools (e.g., [16, 17]); these might explain why Finnish school staff reported so many negative experiences of their working conditions. It is estimated that 1300 school buildings in Finland suffer from damp and mould [27]. There have been discussions on subjects including whether problems of indoor air quality only affect schools in Finland, and this topic has been widely researched (e.g., $[16,17])$. Dangerous structures and air-conditioning systems coupled with mould problems resulting from these issues, have been identified; these faults particularly affect Finnish buildings constructed between 1960 and 1980 [27]. Of course, it may be that there are no such concerns in Estonia because they are, as yet, unaware of such problems in their schools. Alternatively, Estonia is still quite a new state and the development of schools (working methods as well as physical school premises) is still on-going. For instance, there has been development work to improve the physical working conditions, which staff have been satisfied with.

In Finland, however, providing occupational healthcare for school staffs is a statutory requirement [28, 29]: a similar system in Estonia is only just starting. In Finland, individuals are more likely to demand services from occupational healthcare, with its multi-professional teams and diverse operational models (e.g. health check-ups by an occupational health nurse and a doctor and if needed, check-ups by physiotherapists and psychologists, visits to the work place etc.) than their Estonian counterparts, where in practice, the occupational healthcare offered to school staff is often just a health check-up by a doctor. However, based on the results, many Finnish respondents also feel that there remains a great deal to improve with regards to the occupational healthcare provided to them. For example, school staff are often not sufficiently aware of the diverse services available from their occupational healthcare system (such as details of the types of health checks done, reminders of age-related check-ups and the details of work place visits). Furthermore, occupational healthcare providers tend to concentrate too much on the individual, whereas they ought to consider the whole work community when developing occupational wellbeing.

The relationship between the results of this survey and the background variables was also considered (see Table 3). The schools in this study were chosen from the SHE network's schools in Finland and Estonia, and were comprehensive schools (including pre-schools) and upper secondary schools. One limitation to this study could be that in Estonia more voluntary participants involved from upper secondary schools than in Finland (see Table 1). Similarly, in Finland most participants were from comprehensive schools. However, in this study, statistically significant connections between the background variable of 'my workplace' and the sum variables of 'worker and work' and 'working conditions' were exceedingly marginal (see Table 3). Instead, 'profession' seemed to produce several statistically significant connections in relation to the sum variables of 'worker and work' and 'working conditions' in Finland and Estonia. In addition, there was very little research information available on the occupational well- being of school staff from this perspective. Therefore, in this article, it was decided that only the statistical differences between occupational groups would be described in detail (Table 4), although it is also important to research the other background variables behind the school staff members' wellbeing in the future.

Based on the background variable 'profession', it appears that the principals, school directors, school nurses and the other occupational group (cook, cleaner or other) in this study were the most content with their occupational wellbeing relating to the aspects of 'worker and work' and 'working conditions'. Therefore, the administrator staff's higher incomes than those of the lower level occupations do not appear to affect occupational well-being satisfaction in this study. The results cannot be generalized on the basis one study, so this will require further research. Conversely, the occupational groups that were most involved in working directly with the pupils (subject, special and primary school teachers and other support staff in the school, including psychologist, social worker, remedial teacher, school helper) expressed the greatest demand for development of their work, work-related resources, and working conditions, in both Finland and Estonia. It appears that those working in school management consider their work and working conditions to be reasonable, and those in senior positions tend to have adequate resources in relation to the demands of their work, even though the results indicate that they have a busy work schedule. A school management that is healthy and feels well creates a solid foundation for the well-being and development actions of the entire school; a healthy school head also has more energy to take care of and support other school staff in their teaching work and in promoting well-being. Nevertheless, the results support the view that the different needs of professional groups must be taken into consideration in development actions, so that the well-being of the entire staff can be addressed. The occupational wellbeing of the whole school staff also has a significant effect on the health, well-being and quality of results of the pupils in the school (see e.g., [11]).

\section{CONCLUSION}

It is essential to develop the occupational well-being of school staff so that they will have appropriate resources to handle their work and its demands. The results of this research show that staff members have particularly mentally stressful jobs in both Finnish and Estonian schools and that there is a lot of improvement required to their working conditions. The results indicate that Estonians view their working conditions more positively than Finns. The study does not clearly explain the difference between the results from Finland and Estonia, and therefore further research is needed in this area. In conclusion, we may consider that healthy staff members have more energy to handle their work and this has an effect on the well-being and learning of children and adolescents. Therefore, it is important to create research-based intervention projects to promote the occupational well-being of school staff that will, in addition to the practical development work that occurs at target 
schools, produce a wider, evidence-based theoretical foundation for the promotion of the occupational well-being of school staff by principals, school staff, health nurses, occupational health nurses and other co-operative teams, both nationally and internationally.

\section{CONFLICT OF INTEREST}

The authors confirm that this article content has no conflicts of interest.

\section{ACKNOWLEDGEMENT}

None declared.

\section{RERERENCES}

[1] Saaranen T, Tossavainen K, Turunen H, Vertio H. Occupational well-being in a school community staff's and occupational health nurses' evaluations. Teach Teach Educ 2006; 22(6): 740-52.

[2] Jin P, Yeung AS, Tang T-O, Low R. Identifying teachers at risk in Hong Kong: Psychosomatic symptoms and sources of stress. J Psychosomat Res 2008; 65(4): 357-62.

[3] Lorento PL, Salanova SM, Martínes MI, Schaufeli W. Extension of the job demands-resources model in the prediction of burnout and engagement among teachers over time. Psicothema 2008; 20(3): 354-60.

[4] Konu A, Viitanen E, Lintonen T. Teachers' wellbeing and perceptions of leadership practices. Int J Workplace Health Manag 2010; 3(1): 44-57.

[5] Wu S, Li J, Wang M, Wang Z, Li H. Short communication: intervention on occupational stress among teachers in the middle schools in China. Stress Health 2006; 22(5): 329-36.

[6] Bauer J, Unterbrink T, Hack A, et al. Working conditions, adverse events and mental health problems in a sample of 949 German teachers. Int Arch Occup Environ Health 2007; 80(5): 442-9.

[7] Bradley G. Job tenure as a moderator of stressor-strain relations: a comparison of experienced and new-start teachers. Work Stress 2007; 21(1): 48-64.

[8] Morena-Abril O, Luna-del-Castillo J. D, Ferdandez-Molina C, et al. Factors associated with psychiatric morbidity in Spanish schoolteachers. Occup Med Oxf 2007; 57(3): 194-202.

[9] Yang X, Ge C, Hu B, Chi T, Wang L. Relationship between quality of life and occupational stress among teachers. Pub Heal 2009; 123(11): 750-5.

[10] Fernandes MH, Rocha VM. Impact of the psychosocial aspects of work on the quality of life of teachers. Rev Bras Psiquiatr 2009; 31(1): 15-20.

[11] Spilt JL, Koomen HMY, Thijs JT. Teacher wellbeing: the importance of teacher-student relationship. Educ Psychol Rev 2011; 23(4): 457-77

[12] Chiu TTW, Lam PKW. The prevalence of and risk factors for neck pain and upper limb pain among secondary school teachers in Hong Kong. J Occup Rehabil 2007; 17(1): 19-32.
[13] Bauer J, Unterbrink T, Hack A, et al. Working conditions, adverse events and mental health problems in a sample of 949 German teachers. Int Arch Occup Environ Health 2007; 80(5): 442-49.

[14] Sveinsdóttir H, Gunnarsdóttir H, Friðriksdóttir H. Self-assessed occupational health and working environment of female cabin crew, nurses and teachers. Scand J Caring Sci 2007; 21(2): 262-73.

[15] Perkiö-Mäkelä M. Koulutus (Education). In: Kauppinen T, Hanhela R, Kandolin J, et al., Eds. Työ ja terveys Suomessa 2009 (Work and Health in Finland 2009), Työterveyslaitos, Helsinki, Sastamala: Vammalan kirjapaino Oy 2010, pp. 234-8.

[16] Putus T. Working conditions of the school and their evaluation. In: Rimpelä M, Fröjd S, Peltonen H, Eds. Promotion of welfare and health in the basic teaching 2009. Basic report). Vammalan Kirjapaino Oy 2010; pp. 116-27.

[17] Patovirta R. Teachers health in moisture-damaged schools: a follow-up study. publications of the national public health institute A5, Kuopio: Kopijyvä Oy 2005.

[18] Sahakian NM, White SK, Park J-H, Cox-Ganser JM, Kreiss K. Identification of mold and dampness-associated respiratory morbidity in 2 schools: comparison of questionnaire survey responses to national data. J School Health 2008; 78(1): 32-7.

[19] Salo PM, Sever ML, Zeldin DC. Indoor allergens in school and day care environments. J Allergy Clin Immunol 2009; 124(2): 185-94.

[20] Whelan EA, Lawson CC, Grajewski B, et al. Prevalence of respiratory symptoms among female flight attendants and teachers. Occup Environ Medicine 2003; 60(12): 929-34.

[21] Seibt R, Matz A, Hegewald J, Spitzer S. Working conditions of female part-time and full-time teachers in relation to health status. Int Arch Occup Environ Health 2012; 85(6): 675-87.

[22] Savolainen A. School as a worksite. self-assessment and development needs for working conditions as experienced by students and school personnel. Acta Universitatis Tamperensis 830 Tampere: Tampere University Press Oy 2001.

[23] Saaranen T, Sormunen M, Streimann K, et al. The occupational well-being of school staff and maintenance of their ability to work in Finland and Estonia: focus on the school community and professional competence. Health Edu 2012; 112(3): 236-55.

[24] Ritvanen T. Seasonal psychophysiological stress of teachers related to age and aerobic fitness. Kuopio University Publication D, Medical Sciences 135, Kuopio: Kopijyvä 2006.

[25] Saaranen T, Tossavainen K, Turunen H, Vertio H. Development of occupational well-being in the Finnish European network of health promoting schools. Health Edu 2006; 106(2): 133-54.

[26] Polit DF, Beck CT. Nursing research. generating and assessing evidence for nursing practice. $9^{\text {th }}$ ed. Philadelphia: Lippincott Williams \& Wilkins 2012.

[27] Finland's ministry of the environment (Ympäristöministeriö ). Hallitus linjasi kosteus- ja hometalkoiden keskeiset toimenpiteet, tiedote 12.5.2010 (in Finnish) Available from: http://www. ymparisto.fi/default.asp?contentid $=358286 \&$ lan $=$ fi $[$ Retrieved 2012 March 14]

[28] Occupational Health Care Act No. 1383/2001 Available from: http://www.finlex.fi/en/laki/kaannok-set/2001/20011383 [Retrieved 2012 March 14].

[29] Occupational Safety and health Act No. 738/2002 Available from: http://www.finlex.fi/en/laki/kaan-nokset/2002/en20020738.pdf [Retrieved 2012 March 14].

\section{(C) Saaranen et al.; Licensee Bentham Open.}

This is an open access article licensed under the terms of the Creative Commons Attribution Non-Commercial License (http://creativecommons.org/licenses/ by-nc/3.0/) which permits unrestricted, non-commercial use, distribution and reproduction in any medium, provided the work is properly cited. 